\title{
A case study involving a blunt abdominal trauma leading to disruption of the aortic bifurcation in an infant
}

\author{
Estudo de caso de trauma abdominal contuso levando \\ à ruptura da bifurcação aórtica em criança
}

Seleno Glauber de Jesus-Silva', Rodolfo Souza Cardoso', Melissa Andreia de Moraes Silva', Luiz Gonzaga Fernandez Maringolo', Marcelo Mendonça Rodrigues' ${ }^{1}$ Fausto Miranda Jr. ${ }^{2}$

\begin{abstract}
The incidence of aortic disruption secondary to blunt abdominal trauma is rarely reported in the pediatric population. In general, most of the cases described are the result of motor vehicle accidents. We report on the treatment and outcomes of a 5 -year-old child with aortic bifurcation disruption secondary to an unusual case of blunt abdominal trauma who was admitted to the emergency room in hypovolemic shock and subjected to immediate exploratory laparotomy and vascular repair. The mechanical forces involved in aortic disruption and the management options for repair and treatment of this injury will be discussed.
\end{abstract}

Keywords: child; wounds and injuries; multiple trauma; abdominal aorta; abdominal injuries; vascular system injuries.

\section{Resumo}

A incidência de ruptura aórtica secundária a um trauma abdominal contuso é uma condição extremamente rara e pouco relatada na população pediátrica. Em geral, a maioria dos casos descritos é devida a acidentes automobilísticos. Descrevemos o caso de uma criança de cinco anos de idade, vítima de trauma abdominal contuso de etiologia incomum, a qual foi admitida em sala de emergência em choque hipovolêmico e submetida a laparotomia exploradora, com o reparo de uma laceração da bifurcação aórtica. Serão discutidas as forças mecânicas envolvidas e as opções de tratamento para esse tipo de lesão.
\end{abstract}

Palavras-chave: criança; ferimentos e lesões; traumatismo múltiplo; aorta abdominal; traumatismos abdominais; traumatismos do sistema vascular. 


\section{INTRODUCTION}

Trauma is the most frequent cause of morbidity and mortality in the pediatric population. However, intra-abdominal arterial lesions are rare, occurring in only $2.4 \%$ of blunt abdominal trauma cases in children. Only $0.11 \%$ of these cases involve the abdominal aorta. ${ }^{1}$ Descriptions of a total of 21 cases of abdominal aortic trauma in children were published from 1966 to 2012 and most of these cases involved motor vehicle collisions. ${ }^{2-8}$ Clinical presentations ranged from stable and asymptomatic patients to cases with rupture and hypovolemic shock.

In this report, we describe a case of aortic bifurcation rupture in a 5-year-old victim of blunt abdominal trauma who survived after emergency surgical repair.

\section{CASE REPORT}

A 5-year-old female child suffered an impact on the anterior abdominal wall resulting from a fall while trying to climb a laundry sink. The victim was brought to the emergency room by family members in an unconscious state with bruising at the anterosuperior iliac spine. Upon physical examination the victim had open airways, hypotension $(70 / 30$ $\mathrm{mmHg}$ ), tachycardia (165 bpm), no signs of head or chest trauma and no external bleeding. After orotracheal intubation and stabilization using 20 $\mathrm{ml} / \mathrm{kg}$ of warm crystalloids, blood pressure levels improved, but abdominal wall distension, tachycardia and the absence of femoral pulses were observed. Abdominal ultrasound revealed a retroperitoneal hematoma near the left common iliac artery.

Exploratory laparotomy was immediately performed using a midline incision. Two lacerations (without enteral fluid leakage) were identified, one in the mesentery and the other along the mesenteric border of a segment of the small intestine, and a large expanding retroperitoneal hematoma was also identified. The infrarenal aorta was clamped, but isolation of both iliac arteries was not feasible due to extensive hematoma to the pelvis. No intravenous heparin was administered because of hemorrhagic shock. Exploration of the hematoma revealed an almost complete rupture of the aortic bifurcation (Figure 1). After due isolation of vascular structures and local heparinization, the rupture was repaired using a simple 5-0 polypropylene suture with a total of nine separate stitches (Figure 2). After releasing the clamps, absence of the left femoral pulse was observed. This was treated using a transverse arteriotomy and a simple common iliac artery

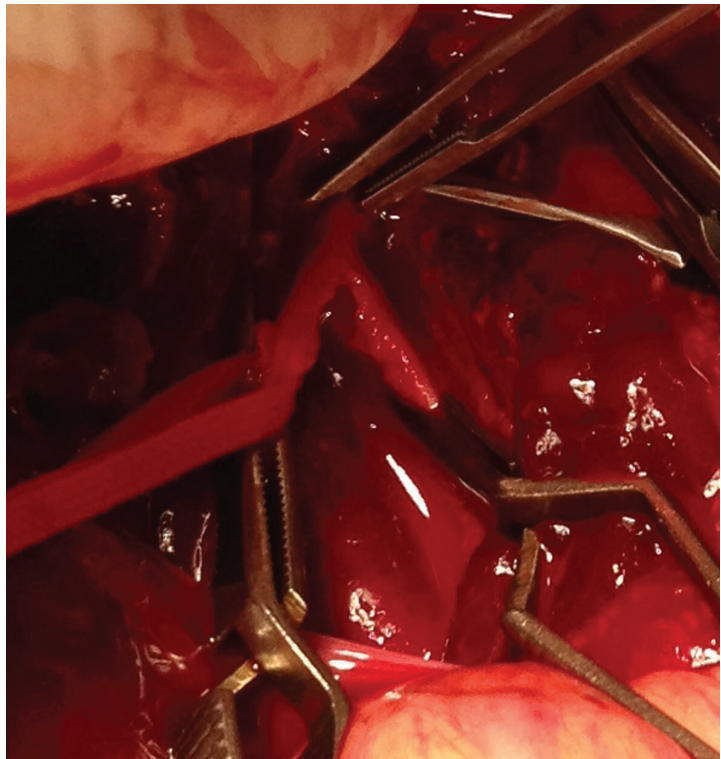

Figure 1. Initial appearance of the aortic bifurcation. An almost complete rupture was observed.

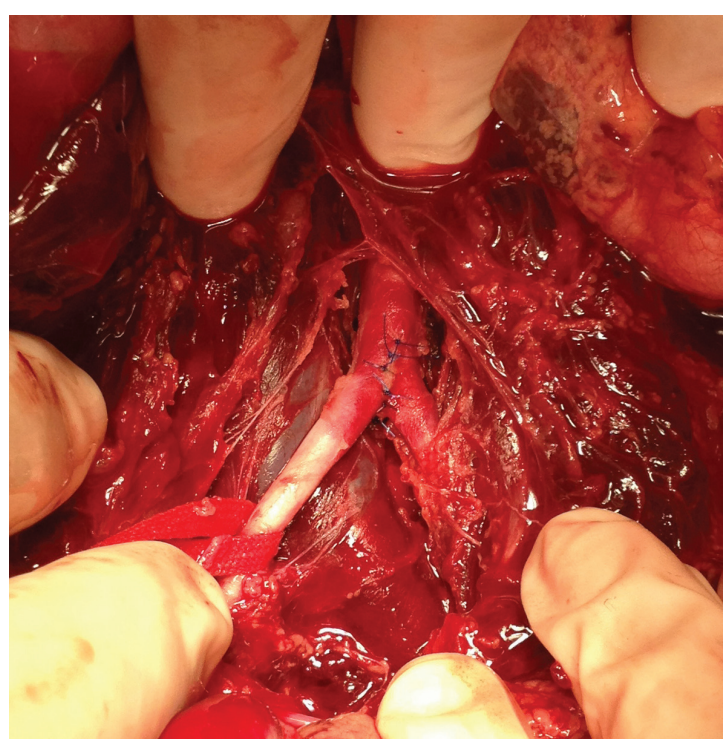

Figure 2. Final appearance of the aortic bifurcation after primary repair and clamp release.

thrombectomy. After reviewing hemostasis and closure of the retroperitoneum, the small intestine and mesentery lesions were sutured using absorbable sutures. The abdominal wall was closed without problems. The child was transferred to the intensive care unit, extubated on the first postoperative day and remained under observation for three days. Blood pressure levels remained stable, red blood count was normal and bilateral pedal and posterior tibial pulses were observed (ankle-brachial index of 1.0). The victim had two febrile peaks on the sixth and seventh 


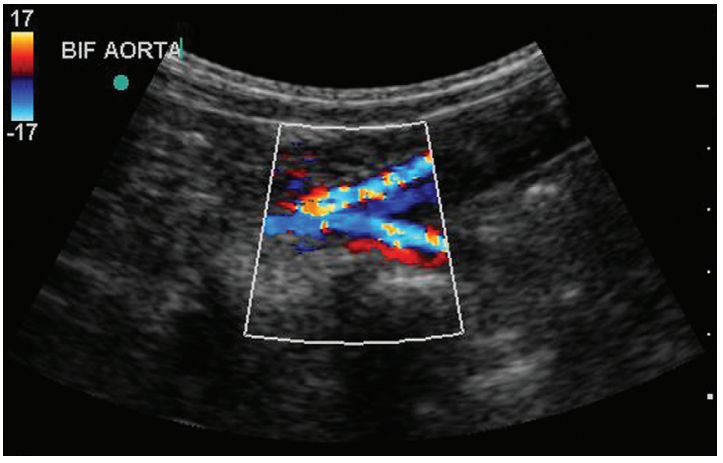

Figure 3. Duplex scan of the aortic bifurcation at 15 days after hospital discharge. Aortic, iliac and femoral systolic velocity peaks were normal.

postoperative days, which were interpreted as secondary to resorption of the hematoma and treated conservatively. No signs or symptoms of abdominal compartment syndrome were detected. The patient was discharged on the eighth postoperative day, exhibiting normal and uneventful feeding, and returned for an outpatient visit within 15 days, showing no signs of disease. Aortoiliac ultrasound was performed to document the patency of the aortic bifurcation (Figure 3). Currently, the child remains asymptomatic, practicing usual activities.

\section{DISCUSSION}

Blunt trauma to the abdominal aorta is an extremely rare condition in all age groups, accounting for only 0.01 to $0.07 \%$ of cases of blunt trauma. However, abdominal aortic injury has been associated with a mortality rate of $32 \%{ }^{9,10}$ Incidence in the pediatric population is even lower and the condition has only been reported in small series and cases. This study is the 22nd case to be reported of blunt abdominal aortic trauma in children less than 16 years of age and just the fourth report of a case of aortic bifurcation rupture found in the literature reviewed. ${ }^{4,6}$

Blunt aortic lesions can range from an intimal flap to thrombosis, pseudoaneurysm formation, intramural hematoma, rupture or transection of the aorta and late aortic stenosis. ${ }^{9,11}$ Pseudoaneurysms are the result of weakening of the aortic wall and are often diagnosed weeks or months after the initial trauma, either after the appearance of a palpable abdominal mass or through unrelated imaging. Aortic ruptures are less common. Lacerations and ruptures of the thoracic aorta have been associated with deceleration mechanisms (primarily observed in motor vehicle accidents), but since the abdominal aorta is fixed to the spine it is more susceptible to the action of direct forces. ${ }^{12}$ Unlike the rigid atherosclerotic aorta observed in adults, in children and infants the aorta is elastic, and therefore resistant to greater shear forces. ${ }^{5}$ The different responses of the abdominal aorta and the iliac arteries to extrinsic compression cause disruption at the point of greatest stress, the bifurcation. Therefore, rupture of the aortic bifurcation in a 5-year-old child must involve great pressure exerted against the lumbar and sacral vertebrae.

Due to the wide distribution of forces inside the abdominal cavity associated injuries are common, primarily gastrointestinal lacerations and medullary dysfunction. ${ }^{1,13}$ Paraplegia may also be present as a result of concomitant trauma to lumbar vertebrae ${ }^{14}$ or, in cases of aortic thrombosis or spinal cord ischemia, because of occlusion of lumbar arteries. ${ }^{2}$

Emergency room presentations can vary greatly, ranging from hemorrhagic shock with indications for immediate exploratory surgery to cases in which the patient is clinically stable and proper imaging studies can be performed..$^{15}$ In the second of these possibilities, clinical observation and treatment alone may be sufficient, since in cases of dissection or intimal flap spontaneous healing of the injury is possible. ${ }^{3}$

In the case reported here, the child was brought to the emergency room by family members because they lived near the hospital and the medical rescue team would have taken a long time to arrive. Despite the fact that the child was hypotensive, which could have been a protective factor against expansion of the lower retroperitoneal hematoma, the risks are much greater in the absence of prehospital care.

Surgical options employed in cases of aortic ruptures include simple stitches and use of autologous vein or polytetrafluoroethylene (PTFE) patches. Simple stitches tend to be the best treatment option, but in cases of tissue loss sutures cannot be used without reducing the vascular lumen. The strategy of separate sutures avoids the vessel narrowing as it grows, particularly when non-absorbable sutures are used. Venous patches are useful in cases of intracavitary contamination, but can lead to aneurysmal degeneration of the arterial wall. Although PTFE patches are typically oversized to follow body growth, the use of this method should be avoided in young children. ${ }^{4}$

In Brazil, concrete laundry sinks attached to the wall are common, particularly in the poorest areas. These sinks weight more than $40 \mathrm{~kg}$ and are often not adequately fixed. Children can suffer blunt traumas to the level of the upper abdomen (liver, pancreas, 
stomach) if these sinks fall when they are attempting to climb them. ${ }^{16}$

Despite the outcome of this in-hospital case, medium and long-term surveillance is needed to assess the growth of aortic bifurcations over the years and whether this particular type of injury leads to restenosis or weakening of the vessel wall.

\section{REFERENCES}

1. Hammer CE, Groner JI, Caniano DA, Hayes JR, Kenney BD. Blunt intraabdominal arterial injury in pediatric trauma patients: injury distribution and markers of outcome. J Ped Surg. 2008;43:916-23. PMid:18485966. http://dx.doi.org/10.1016/j.jpedsurg.2007.12.039

2. McCarthy MC, Price SW, Rundell WK, et al. Pediatric Blunt Abdominal Aortic Injuries: Case Report and Review of the Literature. J Trauma. 2007;63:1383-7. PMid:17308495.

3. Heck JM, Bittles MA. Traumatic abdominal aortic dissection in a 16-month-old child. Pediatr Radiol. 2009;39:750-3. PMid:19340420. http://dx.doi.org/10.1007/s00247-009-1224-7

4. Lin PH, Barr V, Bush RL, Velez DA, Lumsden AB, Ricketts J. Vasc Endovasc Surg. 2003;37(4):289-92. PMid:12894372. http://dx.doi. org/10.1177/153857440303700409

5. Burjonrappa S, Vinocur C, Smergel E, Chhabra A, Galiote J. Pediatric blunt abdominal trauma. J Trauma. 2008;65:E10-2. PMid:18580504. http://dx.doi.org/10.1097/01.ta.0000208140.50947.4e

6. Blanco FC, Powell DM, Guzzetta PC, Burd RS. Aortic bifurcation rupture after blunt abdominal trauma in a child: a case report. J Ped Surg. 2011;46:1452-4. PMid:21763853. http://dx.doi. org/10.1016/j.jpedsurg.2011.03.072

7. Fox JT, Huang YV, Barcia PJ, Beresky RE, Olsen D. Blunt Abdominal Aortic Transection in a Child: Case Report. J Trauma. 1996;41(6):1051-3. PMid:8970563. http://dx.doi. org/10.1097/00005373-199612000-00020

8. Berthet S, Quiviger S, Kurzenne JY, Djafari M, Pradines P, Coache C. Abdominal aortic injury in a child: seat-belt syndrome (French). Arch Ped. 2010;17:1661-3 (French). PMid:20888197. http://dx.doi. org/10.1016/j.arcped.2010.08.011

9. Muñiz AE, Haynes JH. Delayed Abdominal Aortic Rupture in a Child with a Seat- Belt Sign and Review of the Literature. J Trauma. 2004;56:194-7. PMid:14749590. http://dx.doi.org/10.1097/01. TA.0000033141.40817.E9

10. Shalhub S, Starnes BW, Tran NT, et al. Blunt abdominal aortic injury. J Vasc Surg. 2012;55:1277-86. PMid:22322120. http://dx.doi. org/10.1016/j.jvs.2011.10.132

11. West $\mathrm{CH}$ Jr, Johnson LW, Doucet $L$, Shah M, Khan I, Heldmann $M$. Acute aortic occlusion in a child secondary to lap-belt injury treated with thromboendarterectomy and primary repair. J Vasc Surg. 2011;54:515-8. PMid:21316902. http://dx.doi.org/10.1016/j. jvs.2010.12.031

12. Roth SM, Wheeler JR, Gregory RT, Gayle RG, Parent FN III, Demasi R. Blunt injury of the abdominal aorta: a review. J Trauma. 1997;42:748-55. PMid:9137272. http://dx.doi. org/10.1097/00005373-199704000-00032
13. Anderson SA, Day M, Chen MK, et al. Traumatic aortic injuries in the pediatric population. J Ped Surg. 2008;43:1077-81. PMid:18558186. http://dx.doi.org/10.1016/j.jpedsurg.2008.02.030

14. Choit RL, Tredwell SJ, Leblanc JG, Reilly CW, Mulpuri K. Abdominal aortic injuries associated with Chance fractures in pediatric patients. J Ped Surg. 2006;41:1184-90. PMid:16769359. http:// dx.doi.org/10.1016/j.jpedsurg.2006.01.069

15. Jakob H, Lustenberger T, Schneidmüller D, Sander AL, Walcher F, Marzi I. Pediatric polytrauma management. Eur J Trauma Emerg Surg. 2010;36:325-38. http://dx.doi.org/10.1007/ s00068-010-1125-3

16. Mattos AA, Imamura JH, Vieira GK, Santos EL. The tank syndrome: case report. Pediatria (São Paulo). 2008;30(3):185-8. (Portuguese).

Correspondence

Seleno Glauber de Jesus-Silva Rua Miguel Viana, 420 - Morro Chic CEP 37500-080, Itajubá, (MG), Brazil Tel.: +55 (35) 3629-7600 Fax: +55 (35) 3621-3624 E-mail: selenoglauber@gmail.com

Author information

SGJS é Professor Assistente da Disciplina de Introdução aos Procedimentos Minimamente Invasivos da Faculdade de Medicina de Itajubá (FMIt) e Cirurgião Vascular do Hospital Escola da FMIt

(HE/FMIt)

RSC é Professor Assistente da Disciplina de Introdução aos Procedimentos Minimamente Invasivos da Faculdade de Medicina de Itajubá (FMIt) e Cirurgião Vascular do Hospital Escola da Faculdade de Medicina de Itajubá (HE/FMIt)

MAMS é Professora Assistente da Disciplina de Cirurgia Vascular da Faculdade de Medicina de Itajubá (FMIt) e Cirurgiã Vascular do Hospital Escola da FMIt (HE/FMlt).

LGFM é Residente de $2^{\circ}$ ano de Cirurgia Geral do Hospital Escola da Faculdade de Medicina de Itajubá (HE/FMIt). MMR é Professor Assistente da Disciplina de Cirurgia Geral da Faculdade de Medicina de Itajubá (FMIt) e Clrurgião Geral do Hospital Escola da FMIt (HE/FMIt).

FMJ é Professor Titular da Disciplina de Cirurgia Vascular e Endovascular do Departamento de Cirurgia da Escola Paulista de Medicina, Universidade Federal de São Paulo (UNIFESP).

Author contributions Conception and design: SGJS Analysis and interpretation: SGJS, MAMS Data collection: SGJS, LGFM, MAMS Writing the article: SGJS, LGFM Critical revision of the article: RSC, FMJ, MMR Final approval of the article*: RSC, FMJ Statistical analysis: N/A Overall responsibility: SGJS

*All authors have read and approved of the final version of the article submitted to J Vasc Bras. 